Discourse and Communication for Sustainable Education, vol. 10, no. 1, pp. 37-46, 2019

\title{
Examining the Effects of Sustainable Organizational Culture on Academic Achievement
}

\author{
Emrah Özsoy and Osman Uslu \\ Sakarya University, Sakarya, Turkey
}

\begin{abstract}
The purpose of this study is to investigate the effect of faculty culture perceptions of students on their academic achievement. Within the scope of the study, academic achievement was measured only with the Grade Point Average (GPA). Cultural perceptions were measured through organizational structure, commitment, symbols, power distance, and communication/relationship dimensions. The data was gathered from senior students in a business school operating in a public university in Turkey. Participants consist of the students who study in 2011-2012, 2012-2013 (questionnaires were completed before graduation), and 2018-2019 periods. A total of 359 valid questionnaire forms were obtained. 42 of the questionnaire forms were eliminated by the control questions included in the questionnaire. Within this scope, 111 questionnaire forms from 2011/2012, 163 from 2012/2013, and 85 from the 2018/2019 period were obtained as valid questionnaire forms. The data was collected by the random sampling method using convenience sampling. According to research findings, only the commitment dimension of the organizational culture positively predicted students' academic achievement. Conversely, it was found that other dimensions of organizational culture didn't predict students' academic achievement. Findings were discussed and suggestions were presented for practitioners and future research.
\end{abstract}

Keywords: organizational culture, sustainability, academic achievement, university students.

\section{Introduction}

The importance of the human factor is increasing day by day in terms of the success of all organizations, whether they are profit or non-profit oriented. Factors such as effective human resource policies (Alkalha et al., 2012) and strategies, a climate of cooperation and trust (Asencio, 2016), and a positive corporate culture (Leithy, 2017) are all important issues for organizations. Previous research in the field found, there is a direct association between organizational culture and organizational performance (Yılmaz \& Oğuz, 2001, 107; Lee \& Yu, 2004; Zakari \& Poku, 2013). It is possible to mention various success indicators for each organization. Indicators such as individual performance, organizational performance, financial performance, employee satisfaction 
level and optimum stress level are only some of them. Factors such as creative thinking, being sensitive to the problems, offering effective solutions to these problems, following the changes in the world and high academic achievement can be shown as indicators of student achievement in higher education. Undoubtedly there are many factors affecting university students' achievements (Szell, 2013; Marzano, Waters, \& McNulty, 2005). Among them; the students' ability to receive education in an appropriate department in line with their abilities and expectations, the quality of the academicians, the organizational structure and the culture of the educational institutions can be considered as important critical premises. Despite all these factors, it is determined that there is not enough numbers of studies in academic institutions about the effect of organization culture on students' academic averages. Moreover, studies on the relationship between culture and achievement focus mostly on primary and secondary level schools rather than higher education institutions (Koçyiğit, 2017; Smith, 2014). For this reason, in this study, it is aimed to examine the association between academic achievement and organizational culture perceptions of university students. Academic achievement is a very comprehensive concept. Factors such as the conduct of scientific studies, bringing solutions to the problems of the society, adapting to the world order, solving problems related to the profession, and students' academic averages can be evaluated within the scope of academic achievement. However, in the current study, the only factor considered as a reflector of academic achievement was the students' grade point averages. In the scope of the study, first, the conceptual framework of culture and organizational culture were discussed. Secondly, the theoretical and empirical background of the association between students' achievement and culture was discussed in the context of the research background. Thirdly, the findings of the study were evaluated and related suggestions were presented.

\section{Culture as the Fourth Pillar of Sustainability}

Culture has many different definitions, as a concept that is frequently used in every field of life. Parekh (2002) defined culture as a system of beliefs and customs used in understanding, arranging, and structuring the individual and collective lives of a group of people. Hofstede $(2001,9)$, described culture as a collective programming of the mind that distinguishes a group or human from others. Culture is a collective phenomenon that embodies the reactions of human beings to the uncertainties and chaos that seem inevitable. These responses are divided into two basic categories. The first of these is the shared, emotionally charged belief systems that we know as ideologies in the essence of a culture. And the latter are observable beings that are shown and confirmed by members of the culture (Eisenberg et al., 2018; Trice \& Beyer, 1993, 2; Hatch, 2013). It is possible to define organizational culture in various ways, but in general, it can be defined as a combination of meanings, beliefs, assumptions, understandings, norms, and values that are shared among the members of a group (Hatch, 2013, 159).

\section{Heading Towards Sustainable Achievement}

Education can affect the future of an individual to a great degree. University period is one of the most important stages of an individual's education. Students who are successful in this period are expected to be more successful in their future lives. Therefore, 
determining the factors affecting the achievement of the students is critical. There are many factors affecting students' achievement, which include physical, spiritual, social, economic, geographic, environment factors (Rençber, 2012, p. 192), family (Abdieva, 2015, p. 898), students' relationships with people, and help-seeking behavior (Özbay, 1997). Although achievement is a relative concept, it can be measured in certain ways. While the achievement of an enterprise is to reach sustainability in return for offering products and services that are beneficial to a given society, the achievement of a nonprofit organization is to operate in a sustainable manner in line with its mission. The achievement of an educational institution is to educate qualified students who will form the basis of a sustainable, strong economy that will benefit science, industry, society, and humanity in line with the basic mission. If educational institutions cannot achieve this mission at a reasonable standard, a significant reduction in the competitiveness of countries in the global world may occur. Therefore, achievement in education depends not only on day-to-day improvements but also on creating a sustainable quality with long-term strategic approaches. For this reason, it is necessary to examine the factors affecting the students' achievement in their university education which is one of the most dynamic stages of education life. Several studies have been conducted to investigate the association between organizational culture and organizational performance. In the context of Turkey there is some research conducted on university students (Ates, Teksöz \& Ertepinar, 2017) or teachers (Atmaca, 2017), there are few studies examining the association between perceptions of educational institutions' culture and students' academic achievemen

\section{Research Background}

In the literature, it is emphasized that there is a strong association between the organizations' cultural characteristics and its members' achievement (Erdem \& İşbaş1, 2001, p. 34). It is expected that employees will be successful in the cases where the individual-organization compliance is high and thus the achievement of the organization will be affected positively. When we look at successful organizations, it is observed that there are employees or individuals who adopt the values of the organization as an organizational culture. In successful organizations, it can be observed that there are employees or individuals who assimilate values parallel to organizational purposes as an organizational culture. In short, organizations in which individuals can harmonize themselves with the organization and who can self-sacrifice for the organization are successful (Köse et al., 2001, p. 227). For this reason, culture and sub-cultures must be in harmony. If it is effected, then achievement will be obtained by creating strong cultures. As the power and effect of the subculture may change, the opinions of sub-cultures are of great importance for the organization (Y 1lmaz \& Oğuz, 2005, p. 110). Macneil et al. $(2009$, p. 73$)$ stated that the most important action a leader will undertake is to pay attention to the organizational culture and to deal with it, according to the reports of the organization theorists. In literature, it is seen that there are studies conducted to determine the perceptions of students about culture and to evaluate such perceptions in terms of different variables. For instance, in their study, Erdem and İşbaşı (2001) examined the students' perceptions about actual culture in a faculty. Similar studies were conducted by Alemdar and Köker (2013), Bektaş (2010) and Yılmaz and Oğuz (2005). According 
to these studies' findings, there were differences in the perceptions of the organization's members depending on their demographic characteristics. Macneil et al. (2009) concluded that school culture and climate have effects on student achievement. According to Westhuizen et al. (2005), there are many factors affecting academic achievement of students and the most prominent one of these factors is organizational culture. Demirtaş (2010, p. 211) stated in his research on high school students that the characteristics of the dominant organizational culture would be expected to have a positive or negative effect on student achievement. All these findings reveal that there is a close association between culture and achievement. Moreover, a meta-analysis study including 25 research findings shows that school culture has a significant effect on students' academic achievement (Bektaş et al., 2015). Thus, in the light of the related literature and based on the studies that examine culture-student achievement associations, the following research questions are generated: How do students' perceptions of faculty culture affect their academic achievement? How do students' perception of power distance affects their academic achievement? Do communication/relationship perceptions of students positively affect their academic achievement?

\section{Research Method}

\section{Data Collection ${ }^{1}$}

The required data for the study was obtained from final year students affiliated to a public university's business school operating in Turkey. The main rationale for data collection from senior students is to assume that senior students will spend more time in the faculty for at least four years and will be more familiar with the faculty culture. In the first stage, 111 valid questionnaire forms were obtained from the senior year students in the 2011-2012 period with the convenience sampling method. In the second stage, 163 valid questionnaires were obtained in the 2012-2013 period. And in the final stage, 85 valid questionnaires were obtained in the 2018-2019 period. Thus, a total of 359 valid questionnaires were obtained from senior students in 3 periods. 10 questionnaire forms from 2012, and 23 questionnaires from 2013, and 9 questionnaire forms from 2018 were eliminated through the medium of the control questions placed on the scale (including the negative statements of the same statements in questionnaires). Therefore, 42 questionnaires were eliminated and 359 valid questionnaires were used for the analyses.

\section{Scale}

Organizational culture scale for educational institutions: The scale consisting 19 items and five dimensions (organizational structure, commitment, communication/ relationship, symbols, power distance) which was developed by Erdem and İşbaşı (2001) (in the Turkish language ${ }^{2}$ ) measured the faculty culture of university students. The scale was in a 5-Point Likert format. Sample item (Power distance: Faculty members are in favor of authority in teacher-student relations). 


\section{Research Findings}

Findings related to demographic features of participants are presented in Table 1, descriptive statistics and internal consistencies findings are shared in Table 2, correlation analysis findings are displayed in Table 3, and finally, multiple regression findings are presented in Table 4.

\section{Participants}

$51 \%$ of the participants were male and 4 participants did not report their gender. Students' attendance rate to the courses was found to be as follows: (0-25\%) $2.8 \%$, (26-50\%) 9.5\%, (51-75\%) 35.7\% and (76-100\%) 51\%. In other words, the attendance rate of the students was mostly $50 \%$ and above. 7 participants did not report their attendance rate to the courses. The distribution of the students' graduation periods was as follows: $30.9 \%$ graduated in $2011 / 2012$, $45.4 \%$ graduated in the $2012 / 2013$ period and $23.7 \%$ graduated in the $2018 / 2019$ period.

Table 1

Demographic Findings

\begin{tabular}{lccc}
\hline Variables & Category & Frequency & $\%$ \\
\hline Gender & Male & 183 & 51.0 \\
\cline { 2 - 4 } & Female & 172 & 47.9 \\
\cline { 2 - 4 } & Missing & 4 & 1.1 \\
\hline Attendance rate & $(0-25 \%)$ & 10 & 2.8 \\
\cline { 2 - 4 } & $(26-50 \%)$ & 34 & 9.5 \\
\cline { 2 - 4 } & $(51-75 \%)$ & 128 & 35.7 \\
\cline { 2 - 4 } & $(76-100 \%)$ & 180 & 50.1 \\
\hline Graduation period & Missing & 111 & 30.9 \\
& $2011 / 2012$ & 163 & 45.4 \\
\cline { 2 - 4 } & $2012 / 2013$ & 85 & 23.7 \\
\cline { 2 - 4 } & $2018 / 2019$ & & \\
\hline
\end{tabular}

The internal consistency value of the organizational culture scale for educational institutions used in the research was found to be quite high $(\alpha=0.84)$. Internal consistency findings related to the sub-dimensions of the scale were acceptable ( $\mathrm{min}$ alpha value $=$ 0.66). Alpha values are expected to decrease as the number of items in the scale decreases. For this reason, the internal consistency values of symbols and power distance dimensions were both below 0.70 , which can be explained by the low number of items. The mean value obtained for the total score and the sub-dimensions of the scale was moderate. Since the scale is used in 5-Point Likert format, the average values around 3 can be interpreted as moderate.

The highest score from the sub-dimensions of the scale was power distance perception (3.37). The GPA score of the participants was determined to be 2.37 in a 1-4 grading system. In the 1-4 grading system, 2.37 corresponds to 61.96 out of 100 (http://www.yok.gov.tr). 
Table 2

Descriptive Statistics and Internal Consistencies

\begin{tabular}{lccc}
\hline \multicolumn{1}{c}{ Dimensions } & Mean & S.D & Cronbach's $\alpha$ \\
\hline Organizational Culture Total & 3.14 & 0.58 & .84 \\
\hline Organizational Structure & 2.90 & 0.81 & .71 \\
\hline Commitment & 3.31 & 1.17 & .72 \\
\hline Symbols & 3.25 & 0.92 & .66 \\
\hline Power distance & 3.37 & 0.69 & .69 \\
\hline Communication/Relationship & 3.07 & 0.64 & .73 \\
\hline Grade Point Average (GPA) & 2.37 & 0.50 & \\
\hline
\end{tabular}

Table 3 contains the correlation analysis findings. Accordingly, GPA was positively correlated only in a statistically significant way with the commitment of the organizational culture ( $\mathrm{r}=0.12$; low effect size). Other dimensions did not show significant correlations with GPA. As expected, the sub-dimensions of the organizational culture scale showed significant and positive associations among each other.

Table 3

Correlation Findings

\begin{tabular}{|c|c|c|c|c|c|c|c|}
\hline Dimensions & 1 & 2 & 3 & 4 & 5 & 6 & 7 \\
\hline 1. Grade Point Average (GPA) & - & & & & & & \\
\hline 1. Organizational Culture Total & .07 & - & & & & & \\
\hline 3. Organizational Structure & .04 & $.80 * * *$ & - & & & & \\
\hline 4. Commitment & $.12 *$ & $.66 * * *$ & $.34 * * *$ & - & & & \\
\hline 5. Symbols & .10 & $.51 * * *$ & $.35 * * *$ & $.21 * * *$ & - & & \\
\hline 6. Power distance & .04 & $.57 * * *$ & $.29 * * *$ & $.23 * * *$ & $.27 * * *$ & - & \\
\hline 7. Communication/Relationship & .10 & $.87 * * *$ & $.68 * * *$ & $.39 * * *$ & $.30 * *$ & $.44 * * *$ & - \\
\hline
\end{tabular}

Note. ${ }^{*} p<.05, * \mathrm{p}<.01, * * \mathrm{p}<.001$

Multiple regression analysis was used to test the effect of organizational culture perceptions on academic achievement. Accordingly, in multiple regression analysis only commitment significantly and positively affected GPA, and other cultural dimensions did not influence academic achievement. The effect of commitment on GPA was weak $(B=0.13 \mathrm{p}<0.05)$. Thus, as an answer to the research question it was found that students' perception of faculty culture partly affects students' academic achievement. But only commitment dimension of organizational culture had a positive effect on students' academic achievement whereas the dimensions such as organizational structure, symbols, power distance, and communication/relationship did not have a significant effect on students' academic achievement. 
Table 4

Multiple Regression Findings

\begin{tabular}{|c|c|c|}
\hline \multirow{2}{*}{ Independent variables } & \multicolumn{2}{|c|}{$\frac{\text { Dependent Variable }}{\text { GPA }}$} \\
\hline & $\beta$ & $\mathrm{t}$ \\
\hline Organizational Structure & .04 & .47 \\
\hline Commitment & .13 & $2.19 *$ \\
\hline Symbols & .09 & 1.59 \\
\hline Power distance & .03 & .47 \\
\hline Communication/Relationship & .10 & 1.58 \\
\hline
\end{tabular}

\section{Conclusion}

In the current study, only the commitment dimension of the organizational culture significantly affected the students' academic achievement (in terms of GPA). All other dimensions of organizational culture were not found to be significant predictors of students' GPA. In general, the university culture that contains subcultures from the social culture and the cultures that are specific to faculties have the potential to affect certain variables, especially the students' academic achievement. In the current study, the perception of faculty culture was measured through the dimensions of organizational structure, commitment, symbols, power distance, and communication/relationship. It is possible to mention many factors affecting the academic achievement of students. Examples of these factors include student motivation and interest, staff, campus environment, the region of faculty or university. However, this study focused particularly on the possible impact of faculty culture perception of students', on their academic achievement.

The basis of the individual's sense of belonging to a person, institution or society is the harmony of the set of values and expectations. Otherwise, the person will have a sense of belonging elsewhere and the level of motivation will not reach the ideal level. Although values are generally examined on social issues, they can be also examined individually. For instance, flexibility and autonomy can be considered among the important values that university students can give prominence. It is possible for the faculties to meet the expectations of the students by providing practices required by the modern age and shaping the management philosophy in this direction. For this reason, it is thought that creating a faculty culture that is suitable for the students' set of values, will provide a basis for the students to adapt to the institution more.

Limitations. The measurement of academic achievement based on grade point average obtained during 4 years is an important limitation of the present study. The basic dependent variable was only taken as the grade point average. As a matter of fact, subjects such as professional knowledge and qualifications of the students, the ability to solve the problems were not considered within the scope of academic achievement. 


\section{Suggestions for Further Research}

This may be possible to use different data collection methods and tools in future studies. Especially, focus group studies can be carried out and students' desire about what kind of faculty or university culture they want, can be explored. In this manner, managers of faculties or universities can be more aware of the kinds of improvements that are required. Additionally, there are limited scales that measure faculty cultures, so, it is important to develop new scales to be able to measure faculty or university culture. Also, as cultural sustainability is an important factor (Laine, 2016), it is beneficial to find out the ways to create a sustainable positive culture at the universities.

It is possible of course to mention many factors that may affect the academic achievement of university students (Marzano, Waters, \& McNulty, 2005). In the current study, only the commitment factor predicted students' academic achievement. This finding is consistent with previous research (Bektaş et al., 2015; Bektaş, 2010; Alemdar \& Köker, 2013). This finding reveals that students have higher academic achievement only if they feel that they are committed to their faculty and university. So, it is possible to say that commitment is an important organizational factor for increasing students' achievement. Thus, commitment should be clearly considered by faculty and university authorities in order to increase students' performance. Undoubtedly, it is important that employees or members to feel as a part of their organizations for the sustainability of institutions. Any employee or student, who feels excluded, will not prefer to be part of the institution. It is considered that more research should be conducted in cross-cultural samples on this subject matter, to be able to make more comprehensive conclusions about the effects of university culture (faculty perception) on students' academic achievement. This is because "achievement" is one of the most concrete outcomes possible for students and society. For this reason, it is necessary to examine all factors that might affect achievement in detail, in order to make critical suggestions for the practitioners.

Note:

(1) Some of the findings from the data collected during the 2011-2012 period and 2012-2013 period were presented in the $11^{\text {th }}$ International Conference on Knowledge, Economy \& Management Congress.

(2) The authors utilized some of the items from the scales developed by Şişman (1994) and Berberoğlu (1997).

\section{References}

Abdieva, R. (2015). Üniversite öğrencilerinin başarılarını etkileyen demografik faktörler [Demographic factors affecting the success of university students]. International Conference on Eurasian Economies, 898-901.

Alemdar, M. Y., \& Köker, N. E. (2013). Öğrencilerin okul kültürü algisi üzerine ampirik bir araştirma: Ege üniversitesi iletişim fakültesi örneği [An empirical research on the students' school culture perception: Sample of age university communication faculty]. Global Media Journal, 3(6), 230-261.

Alkalha, Z., Al-Zu'bi, Z. M. F., Dmour, H., Alshurideh, M. T., \& Masa'deh, R. (2012). Investigating the effects of human resource policies on organizational performance: 
an empirical study on commercial banks operating in Jordan. European Journal of Economics, Finance and Administrative Sciences, 51(51), 44-64.

Asencio, H. D. (2016). Leadership, trust, and organizational performance in the public sector. Transylvanian Review of Administrative Sciences, 12, 5-22.

Ates, D., Teksöz, G., \& Ertepınar, H. (2017). Exploring the role of future perspective in predicting Turkish university students' beliefs about global climate change. Discourse and Communication for Sustainable Development, 8(1), 32-52.

Atmaca, Ç. (2017). Effects of contextual factors on ESD in teacher education. Discourse and Communication for Sustainable Education, 8(2), 77-93.

Bektaş, F. (2010). Örgütsel imaj ve örgüt kültürü: öğretmen adayi örnekleminde nedensel bir araştirma. [Organizational image and organizational culture: A casual research in the teacher candidate sample). Journal of Education and Humanities/Theory and Practice, 1(1), 5-18.

Bektaş, F., Çoğaltay, N., Karadağ, E., \& Ay, Y. (2015). School culture and academic achievement of students: a-meta analysis study. Anthropologist, 21(3), 482-488.

Berberoğlu G. (1997). Anadolu Üniversitesi Örgüt Kültürü Çalişmasi [Anadolu University Organizational Culture Study], Unpublished Research.

Demirtaş, Z. (2010). Liselerde okul kültürü ile öğrenci başarisi arasindaki ilişki [The relationship between school culture and student achievement in high schools]. Mustafa Kemal University Social Sciences Institute Journal, 7(13), 208-223.

Eisenberg, A., Ignatjeva, S., Iliško, D., \& Rauckiene-Michaelsson, A. (2018). Adaptation of the organizational learning culture (OLC) dimension methodology in the Israeli local authorities' context. Discourse and Communication for Sustainable Education, 9(1), 50-63.

Erdem, F., \& İşbaşı, J.Ö. (2001). Eğitim kurumlarinda örgüt kültürü ve öğrenci alt kültürünün algilamalari [Organizational culture in educational institutions and perceptions of student subculture]. Akdeniz I.I. Journal, (1), 33-57.

Hatch, M. J. (2013). Organization theory. Modern, symbolic and postmodern perspectives. Oxford University Press: United Kingdom.

Hofstede, G. (2001). Culture's Consequences. Sage Publications: London.

Koçyiğit, M. (2017). The effect of school culture on student achievement. In E. Karadag (Eds). The factors effecting student achievement. Springer, Cham.

Köse, S., Tetik, S., \& Ercan, C. (2001). Örgüt kültürünü oluşturan faktörler [Factors determining organizational culture]. Celal Bayar Üniversity I.I.B.F. Management and Economy Journal, 7(1), 219-240.

Laine, M. (2016). Culture in sustainability in defining cultural sustainability in education. Discourse and Communication for Sustainable Education, 7(2), 52-67.

Lee, S. K. J., \& Yu, K. (2004). Corporate culture and organizational performance. Journal of Managerial Psychology, 19(4), 340-359.

Leithy, W. E. (2017) Organizational culture and organizational performance. International Journal of Economics \& Management Sciences, 6(4), 1-6.

Macneil, A. J., Prater, D. L., \& Busch, S. (2009). The effects of school culture and climate on student achievement. International Journal of Leadership in Education, 12(1), 73-84.

Marzano, R. J., Waters, T., \& McNulty, B. A. (2005). School Leadership that Works: From Research to Results. Alexandria, VA: Association for Supervision and Curriculum Development. 
Özbay, G. (1997). Üniversite öğrencilerinin problem alanlarini belirlemeye yönelik bir ölçek geliştirme geçerlik ve güvenirlik çalişmasi [Validity and reliability study of a scale to determine the problem areas of university students]. Social Sciences Institute, Unpublished Master Thesis, Trabzon K.T.U.

Parekh, B. (2002). Çok Kültürlülüğ̈̈ Yeniden Düşünmek [Rethinking Multiculturalism]. Phoenix Publications, Ankara.

Rençber, B. A. (2012). Üniversite öğrencilerinin akademik başarilarini etkileyen faktörler [Factors which affect academic achievement of university students]. Çankiri Karatekin Üniversitesi SBE Dergisi, 3(1), 191-198.

Şişman, M. (1994). Örgüt Kültürü [Organizational culture]. Anadolu Üniversitesi Yayınları, Anadolu University Publications, 732.

Smith, B. J. (2014). The effect of school culture on student achievement. Doctoral dissertation, East Carolina University.

Széll, K. (2013). Factors determining student achievement. Hungarian Educational Research Journal, 3(3), 55-66.

Trice, H. M., \& Beyer, J. M. (1993). The cultures of working organizations Englewood Cliffs: NJ: Prentice Hall.

Van der Westhuizen, Philip C., Mosoge, M. J., Swanepoel, L. H., \& Coetsee, L. D. (2005). Organizational culture and academic achievement in secondary schools. Education \& Urban Society, 38(1), 89-109.

Yılmaz, K. \& Oğuz, E. (2005). Eğitim bilimleri fakültesi öğrencilerinin fakülte kültürüne ilişkin algilari [The perception of the faculty culture of faculty of education sciences students]. Ankara Üniversitesi Eğitim Bilimleri Fakültesi Dergisi, 38(1), 101-122

Zakari, M., \& Poku, K. (2013). Organizational culture and organizational performance: empirical evidence from the banking industry in Ghana. International Journal of Business, Humanities and Technology, 3(1), 95-107.

Correspondence concerning this article should be addressed to Emrah Özsoy, Sakarya Business School at Sakarya University, Esentepe Campus Room: P 106 Serdivan, Sakarya, Turkey. Email: eozsoy@sakarya.edu.tr 